\title{
The name of the game - the historical names of the Hungarian parliament
}

\author{
dr. hab. György KÉPES
}

\begin{abstract}
Since the introduction of Hungarian as the official language of the Kingdom of Hungary (1844) the Hungarian parliament has officially been called Országgyúlés (in a common but not entirely correct English translation: "National Assembly"). In the "feudal" (estate) period, no such official Hungarian name was in use, and even the Latin denominations changed over time, from the $13^{\text {th }}$ up to the $19^{\text {th }}$ century. The use of the word parliament (parlamentum) was rather exceptional, and appeared in the earliest sources only, while the words congregatio, conventio, comitia and diaeta became common, however none of them exclusive, and all of them frequently used with attributes, in possessive form or in the combinations thereof (as e.g. congregatio generalis, comitia regni or generalis diaeta regni). This study is intending to make an attempt to show the origin, emergence and development of these various Latin expressions, and, in the last part, to present the Hungarian variants as well, also highlighting the importance and criteria of a historical demarcation between the two Hungarian forms of the English expression "national assembly", országgyúlés and nemzetgyúlés.
\end{abstract}

\section{Keywords}

diet, parliament, legislative assembly, estates, popular representation, history of parliamentarism, historical terms for parliaments

\section{Introduction}

The Hungarian Parliament can look back on a many-centuries-long history. Its direct predecessor is a royal judicial assembly that was used to be held by the Hungarian kings in the city of Székesfehérvár traditionally "on the feast day of the holy king", St. Stephen (1000-1038), in order to hear cases. ${ }^{1}$ In the Golden Bull of 1222, Andrew II (1205-1235) promised to hold this meeting in every year, and to let, further to the prelates and barons usually invited since St. Stephen, also his royal servants (servientes), i.e. the free

1 BÓNIS, György: The Hungarian Feudal Diet (13 $13^{\text {th }}-18^{\text {th }}$ Centuries), in: Gouvernés et Gouvernants XXV., Bruxelles 1965, 287-307, (289); ECKHART, Ferenc: Magyar alkotmány- és jogtörténet [Hungarian Constitutional and Legal History], Budapest 2000 (originally written in 1946), 94; SZENTE, Zoltán: A parlamentek története. A korai rendi gyülések kialakulásától a modern népképviseleti törvényhozásokig [A History of the Parliaments. From the Birth of the Early Diets to the Modern Parliaments of Democratic Representation], Budapest 2018, 118. 
men from around the country performing military service for the king, ${ }^{2}$ assemble there and talk to their ruler "if they wish". ${ }^{3}$ However, it is important to mention that these assemblies had a judicial function at that time, and it continued so in the following decades as well (that is why they are usually referred to as the "national days of justice"). ${ }^{4}$

In 1267, when king Béla IV (1235-1270) and his son, royal prince Stephen (king of Hungary as Stephen V, 1270-1272) were forced to confirm the privileges guaranteed by Andrew II in the Golden Bull, ${ }^{5}$ some important additions were made to the above cited text. On one hand, the expression "all the servientes who wish" was replaced with "two or three nobles from each county shall gather", and on the other hand the function of the royal assembly was defined with the following half-sentence: "in their presence satisfaction shall be given to all petitioners for all the damages and injuries caused and committed by anyone whatsoever". 6 From this wording we may not lead to the consequence that the feast days of St. Stephen were thus transformed to a legislative body, but king Béla certainly promised to deal with more general affairs of his noblemen further to hearing their single legal cases only. ${ }^{7}$

While according to the historian Pál Engel, the congregatio of bishops held together with "some of the barons, the envoys of the nobles and those of the Cumans" in 1277, where the fifteen-year-old king Ladislaus IV "the Cuman" (named after the ethnicity of his mother, daughter of a Cuman chieftain) was declared to be of age, can be considered as the first Hungarian diet, ${ }^{8}$ the majority of the Hungarian legal historians are of a different opinion. In a book on the history of the Hungarian parliament published in 1999, written by the professors of the Department of History of the Hungarian State and Law at the

2 BARBER, Malcolm: The Two Cities. Medieval Europe, 1050-1320, London - New York 2004, 41; BÓDINÉ BELIZNAI, Kinga et al.: History of the Hungarian Parliament, in: A magyar országgyúlés történetének képeskönyve [History of the Hungarian Parliament], MEZEY, Barna (ed.), Budapest 1999, 23-37, (23).

3 RADY, Martyn: Hungary and the Golden Bull of 1222, in: Banatica, 24, 2014, 2, 87-108, (92 and 104) - "Ut annuatim in festo sancti regis, nisi arduo negocio ingruente vel infirmitate fuerimus prohibiti, Albe teneamur solemnizare. Et si nos interesse non poterimus, palatinus procul dubio ibi erit pro nobis, ut vice nostra causas audiat et omnes servientes, qui voluerint, libere illuc convenient" (in English: "That we are bound to celebrate the feast of Saint Stephen annually in Székesfehérvár unless we should be beset by some urgent matter or prevented by illness. And if we cannot be present, the palatine will definitely be there for us, and shall hear cases in our place, and all the servientes who wish shall freely assemble there", see BAK, János M. (ed.): Online Decreta Regni Mediaevalis Hungariae. The Laws of the Medieval Kingdom of Hungary, All Complete Monographs 4., Logan 2019, 158 and 160-161, online: https://digitalcommons.usu.edu/lib_mono/4 (Downloaded 16 January 2020).

4 BÓDINÉ BELIZNAl et al., 23.

5 ENGEL, Pál: The Realm of St. Stephen. A History of Medieval Hungary, 895-1526, London - New York 2001, 120. See also: S. KISS, Erzsébet: A királyi generális kongregáció kialakulásának történetéhez, Szeged 1971, 32-33 and 53 .

6 In the Latin text: "Item ordinavimus, quod singulis annis in festo sancti regis unus ex nobis Albam venire debeat et de quolibet comitatu duo vel tres nobiles debeant convenire, ut in eorum presentia de omnibus dampnis et iniuriis per quoscunque datis et illatis omnibus querelantibus satisfiat" (in English: "Further, we ordered that each year at the feast of the holy king, one of us shall come to Székesfehérvár and two or three nobles from each county shall gather so that in their presence satisfaction shall be given to all petitioners for all the damages and injuries caused and committed by anyone whatsoever", see BAK, 184 and 188.

7 SZENTE, Zoltán: Functions of the National Assembly Within the Constitutional Tradition of Hungary, in: Annales Universitatis Scientiarum Budapestinensis de Rolando Eötvös Nominatae. Sectio luridica, Budapest 2005, 93-114, (95).

8 ENGEL, 108. 
University Eötvös Loránd of Budapest, it is emphasised that the general congregatios of 1290 and 1298 can be accepted as parliaments because they "already functioned as a national legislative assembly". In the introduction of his recent publication of the sources of medieval Hungarian law, the historian János M. Bak is also confirming this view: "the coronation decree of Andrew III and the parliamentary decretum of 1298 can be regarded as the earliest true pieces of legislation". ${ }^{10}$

The congregatio of 1290 made a decision on the necessity to hold annual meetings in order "to consider the state of the realm and inquire into the actions of barons - how each behaved in his county and how he maintained the rights of the kingdom". ${ }^{11}$ Furthermore, the preamble of the decree of 5 August 1298 says that the king "convened a general assembly", ${ }^{12}$ and from the wording of the decree itself it is clear that the articles were enacted at the occasion of this meeting, convoked by the last king of the Árpád-dynasty, Andrew III (1290-1301). ${ }^{13}$ Article XVII of the same decree also orders that "all prelates [...] as well as all barons and nobles shall be bound to come together at Rákos near the River Danube [...] in order to review everything contained in the charter of the lord king, and to establish what is necessary". ${ }^{14}$ By these provisions, the medieval parliament of Hungary was born, having very probably developed from the custom of annual royal meetings referred to in the Golden Bull. However, Erzsébet $S$. Kiss mentions that the only known example when a royal prince (namely the son of Béla IV, the later Stephen V) actually celebrated "the feast of the holy king" in Székesfehérvár on 20 August ("the day of St. Stephen") happened in 1260. ${ }^{15}$

9 BÓDINÉ BELIZNAI et al., 23. See also: SZENTE, Zoltán: Az országgyúlés funkciói a magyar közjogi hagyományban [Functions of the Parliament in the Hungarian Constitutional Tradition], in: Jogtörténeti Szemle, 7 , 2005, 2, 9-22, (11); SZENTE, A parlamentek története..., 119.

10 BAK, 4.

11 In the Latin text: "Item in quolibet anno semel omnes barones et nobiles regni nostri Albam ad congregationem debeant convenire [tractantes] de statu regni et inquirentes de factis baronum, qualiter quilibet ipsorum in suis comitatibus processerint et conservaverint iura regni, et secundum sua merita premia et demerita vel commissa supplicia ipso die secundum iudicium nostrum et consiliariorum nostrorum recepturi" (in English: "Further, once each year all the barons and nobles of the realm shall convene at Székesfehérvár, to consider the state of the realm and inquire into the actions of barons - how each behaved in his county and how he maintained the rights of the kingdom - and to receive on the same day their rewards for merits or punishments for omissions and misdeeds in accordance with our judgment and that of our councilors", see BAK, 194 and 202-203.

12 In the Latin text: "Quo viso idem dominus Andreas Spritu Sancto suggerente aures aperuit sue clementie et fidelibus consiliis acquiescens congregationem indixit generalem ad hoc..." (in English: "Having seen this, the same Lord Andrew, guided by the Holy Spirit, opened the ears of his compassion and, accepting faithful counsel, convened a general assembly...", see BAK, 207 and 212.

13 ECKHART, 95; RADY, Hungary and the Golden Bull of 1222, 105.

14 In the Latin text: "Statuimus, ut omnes prelati, quos legitimum impedimentum non detinuerit, necnon et omnes barones et nobiles universi ad quindenas beati Georgii in Racus iuxta Danubium convenire teneantur, ut omnibus ibidem recensitis, que in litteris domini regis expressa continentur, institutis, que necessaria fuerint..." (in English: "We decree that all prelates, not prevented by a legitimate hindrance, as well as all barons and nobles shall be bound to come together at Rákos near the River Danube on the fifteenth day after the Feast of St. George in order to review everything contained in the charter of the lord king, and to establish what is necessary", see BAK, 211 and 220. According to Károly Kmety, the end of the sentence should have been "...que necessaria fuerint statuentur". See KMETY, Károly: A magyar közjog tankönyve [Textbook of the Hungarian Public Law], Budapest 1902, 225 [footnote].

15 S. KISS, 53. 
After the death of Andrew III (that, at the same time, meant the extinction of the male line of the House of Árpád), the estates tried to enforce the royal obligation of holding yearly assemblies. The Angevin king, Charles I (1308-1342), already crowned (unconstitutionally with a supplementary crown instead of the Holy Crown traditionally connected to St. Stephen) in 1301, had to meet this expectation in the first two decades of his reign, but as soon as he was able to consolidate his power, he seemed to be unwilling to continue this practice. ${ }^{16}$ Therefore, in 1318 four Hungarian prelates showed him a copy of the Golden Bull, with Martyn Rady's words: "in the hope that he would acknowledge the royal obligation to convene an assembly". ${ }^{17}$ Nevertheless, the last known diet was convened by him in 1320,18 and his son, Louis I "the Great" (1342-1382) appears not to have held any similar assemblies either - maybe with one exception, in 1351, when he reinforced the provisions of the Golden Bull and the "liberty" (privileges) of the nobles with some amendments at a diet probably convened in Buda. ${ }^{19}$

Not speaking about the difficult years between the death of Louis I and the accession to throne of his son-in-law, Sigismund of Luxemburg (1387-1437), a revival of the Hungarian national assemblies can be observed only in the $15^{\text {th }}$ century, primarily after Sigismund's decease..$^{20}$ It is worth noting that Sigismund himself also made an important contribution to the history of the Hungarian parliament, in 1405, when he invited the deputies of the free towns to the diet the first time in Hungarian history, in order to discuss their matters. ${ }^{21}$ The attendance of the towns at the assemblies through their representatives became regular from the 1440s on, ${ }^{22}$ while right in 1446 hundreds of noblemen, who earlier had also been represented from time to time by deputies chosen at noble assemblies in the counties, ${ }^{23}$ were invited personally to attend the assembly in order to elect John Hunyadi (1387-1456) as regent until Ladislaus $V$ of Habsburg (1440-1457) would come to age. ${ }^{24}$

16 SZENTE, Functions of the National Assembly..., 99; SZENTE, A parlamentek története..., 121.

17 RADY, Hungary and the Golden Bull of 1222, 105; see also: ENGEL, 142.

18 Ibidem, 140.

19 SZENTE, A parlamentek története..., 121.

20 BÓNIS, The Hungarian Feudal Diet..., 290; ECKHART, 95.

21 BÓDINÉ BELIZNAl et al., 24; ENGEL, 218; SZENTE, A parlamentek története..., 122.

22 BÓDINÉ BELIZNAl et al., 25; BÓNIS, The Hungarian Feudal Diet..., 294; ECKHART, 97; RÁCZ, Lajos: A Historical Insight in the Theory and Organization of the Hungarian State, in: The Hungarian State, 1000-2000, GERGELY, András - MÁTHÉ, Gábor (eds.), Budapest 2000, 17-67, (40); SZENTE, Functions of the National Assembly..., 98. Recent historiography mentions that the participation of the delegates of the tows became regular only after 1526. See e.g.: KUBINYI, András: A magyar országgyúlések tárgyalási rendje, 1445-1526 [Operational Rules of the Hungarian Diets, 1445-1526], in: Jogtörténeti Szemle, 8, 2006, 2, 3-11, (4); PÁLFFY, Géza: The Kingdom of Hungary and the Habsburg Monarchy in the Sixteenth Century, New York 2009,22 and 179.

23 BÓdINÉ BELIZNAl et al., 25; ENGEL, 349; RÁCZ, A Historical Insight in the Theory..., 39-40; SZENTE, Functions of the National Assembly..., 98 and 100.

24 ENGEL, 349; SZENTE, A parlamentek története..., 122. 
This personal invitation was transformed to an obligation of attendance in 1458 (by Act XIII), and it led to an unfortunate practice of holding mass assemblies, especially in the Jagiello era (1490-1526), thus after the death of Matthias I Corvinus (1458-1490). ${ }^{25}$ The significance of the diets in the turmoil of the $15^{\text {th }}$ and $16^{\text {th }}$ centuries was enormous. After Sigismund's death, the estates quickly made clear that the election of the king fell into their competence. Further to the election of the ruler, the diet obtained the right to approve royal taxes (by custom already since the mid-16 ${ }^{\text {th }}$ century, and from 1504 also by written law, namely Act I of 1504), ${ }^{26}$ and to "vote recruits" for the king (set up an army for the kingdom) as well. ${ }^{27}$ For the $16^{\text {th }}$ century, the exercise of the legislative power in general also became impossible without the diet: Stephen Werböczy emphasised in Chapter 3 of the Second Part of his famous law book Tripartitum (prepared for the diet in 1514, and first published in 1517) that the king cannot issue statutes by himself, but "once the people are summoned and asked whether such laws are acceptable to them or not, and they approve the laws, then such bills are henceforth to be observed as laws [...]". ${ }^{28}$

During the reign of Matthias Corvinus the diet was convened 25 times, while at the time of the Jagiello kings, Wladislas II (1490-1516) and Louis II (1516-1526), further 42 or $43^{29}$ assemblies were held. Altogether it means an average of one diet a year, not evenly spread: less frequently summoned under the strong-armed leader Matthias and more often at the time of the weaker Jagiello kings (in 1518 not less than threetimes). ${ }^{30}$ After the defeat of the Hungarian troops at Mohács in 1526 against the Ottoman Empire, in the so-called "royal" part of Hungary falling under the rule of Ferdinand I of Habsburg (1526-1564), the practice continued, however, the new king intended to return to the earlier custom (followed by Matthias Corvinus) ${ }^{31}$ of inviting only deputies from the counties. Though it could be interpreted as an infringement of the ancient principle of equal noble privileges

25 BÉRENGER, Jean - KECSKEMÉTI, Károly: Országgyúlés és parlamenti élet Magyarországon, 1608-1918 [Parliament and Parliamentary Life in Hungary, 1608-1918], Budapest 2008, 24-25; ECKHART, 96; KMETY, 243 [footnote]; RADY, Martyn: Law and Ancient Constitution in Medieval and Early Modern Hungary, in: A History of the Hungarian Constitution. Law, Government and Political Culture in Central Europe, HÖRCHER, Ferenc LORMAN, Thomas (eds.), London 2019, 29-45, (35); SZENTE, A parlamentek története..., 255. The legal historian György Bónis mentions four known occasions of mass assemblies in the Jagiello period: 1492, 1498,1518 and 1525. See BÓNIS, The Hungarian Feudal Diet..., 294.

26 Ibidem, 298; ECKHART, 98; SZENTE, A parlamentek története..., 253.

27 SZENTE, Functions of the National Assembly..., 101-102.

28 SZABÓ, Béla: Development of Law in Hungary: the First Eight Centuries, in: The Hungarian State, 10002000, GERGELY, András - MÁTHÉ, Gábor (eds.), Budapest 2000, 130-167, (136-137); SZENTE, A parlamentek története..., 254. The source in Latin: "Attamen princeps proprio motu \& absolute potissimum [...] constitutiones facere non potest sed accersito interrogatoque populo si eis tales leges placeant an ne? qui cum responderint quod sic, tales postea sanctiones [...] pro legibus observantur", see: WERBÖCZY, Stephen: The Customary Law of the Renowned Kingdom of Hungary in Three Parts (1517), Budapest 2005, 228-229. (Based on the first original publication: Tripartitum opus iuris consuetudinarii inclyti regni Hungariæ per magistrum Stephanum de Werbewcz personalis præsentie regiæ maiestatis locum tenentem accuratissime editum, Wien 1517).

29 According to Tibor Neumann, no diet was actually held in 1491, the historical documents referring to it are from later times and were wrongly dated. See NEUMANN, Tibor: Királyi hatalom és országgyúlés a Jagelló-kor elején [Royal Power and Diet at the Beginning of the Jagiello Era], in: Rendiség és parlamentarizmus Magyarországon, a kezdetektól 1918-ig [Estates and Parliamentarism in Hungary, from the Beginning to 1918], DOBSZAY, Tamás et al. (eds.), Budapest 2014, 46-54, (47).

30 ENGEL, 348; RADY, Law and Ancient Constitution..., 35.

31 BÓNIS, The Hungarian Feudal Diet..., 294. 
(una eademque libertas), ${ }^{32}$ the high costs of personal attendance meant such a burden to the less wealthy noblemen that this change has gradually been accepted by them, especially when Pressburg (today: Bratislava, Slovakia) was established as the new location of the diets. ${ }^{33}$

The modern (now also historical) ${ }^{34}$ bicameral structure of the Hungarian parliament was finally set up in 1608 (Act I post coronationem), based on the already established practice of holding separate meetings with the aristocrats in the royal council (before the battle of Mohács in the castle of Buda, during the Habsburgs' reign in different buildings in Pressburg or even Sopron). ${ }^{35}$ This regulation, enacted at the occasion of Matthias II's (1608-1619) accession to the Hungarian throne, made a clear distinction between [1] the house of the praelati (catholic archbishops and bishops), barones (the leading officeholders of the realm) and magnates (male and adult members of the aristocratic families who held no office), ${ }^{36}$ and [2] the chamber of deputies of the noble counties, chapters and convents, and royal free towns. ${ }^{37}$ The prelates, barons and magnates continued to be invited personally (as all of them were, by custom, members of the [larger] royal council, the upper house can be considered as the successor of the latter), ${ }^{38}$ while to the lower house, instead of given persons, the communities (counties, chapter, town) were invited by the king, requesting them to send their delegates (ablegati) to the assembly. ${ }^{39}$ Until 1848, no significant change was made, moreover, not even the April Laws of 1848

32 See Chapter 9 of the First Part ("Primae Nonus") of the Tripartitum. The principle derives from Article XI of Louis I's Decree of 1351: "Ad eorundem etiam nobilium petitionem annuimus, ut universi veri nobiles intra terminos regni nostri constituti, etiam in tenutis ducalibus sub inclusione terminorum ipsius regni nostri existentes sub una et eadem libertate gratulentur", in English: "We grant the petition of these same nobles, that all true nobles established within the borders of our kingdom, including also those living on ducal territory within the borders of our kingdom, should enjoy one and the same liberty". See BAK, 273 and 283.

33 BÓDINÉ BELIZNAl et al., 25; BÓNIS, The Hungarian Feudal Diet..., 293; PÁLFFY, The Kingdom of Hungary..., 179; RÁCZ, A Historical Insight..., 39-40.

34 The Hungarian Parliament has been unicameral since 1945.

35 BÉRENGER - KECSKEMÉTI, 25; CSEKEY, István: Magyarország alkotmánya [The Constitution of Hungary], Budapest 1943, 138-139; PÁLFFY, The Kingdom of Hungary..., 179; RADY, Law and Ancient Constitution..., 37; SZENTE, Functions of the National Assembly..., 101. For the locations see the table in PÁLFFY, Géza: A magyar országgyúlés helyszínei a 16-17. században [Locations of the Hungarian Diet in the $16^{\text {th }}$ and $17^{\text {th }}$ Centuries], in: Rendiség és parlamentarizmus Magyarországon, a kezdetektöl 1918-ig [Estates and Parliamentarism in Hungary, from the Beginning to 1918], DOBSZAY, Tamás et al. (eds.), Budapest 2014, 65-87, (67-68).

36 BÓNIS, The Hungarian Feudal Diet..., 295; ENGEL, 348; PÁLFFY, The Kingdom of Hungary..., 21-22; RADY, Law and Ancient Constitution..., 37; SZIJÁRTÓ, István M.: The Diet: The Estates and the Parliament of Hungary, 1708-1792, in: Bündnispartner und Konkurrenten des Landesfürsten? Die Stände in der Habsburgermonarchie, AMMERER, Gerhard et al. (eds.), Wien - München 2007, 119-139, (124).

37 BÓNIS, The Hungarian Feudal Diet..., 295; ECKHART, 213; SZENTE, A parlamentek története..., 256-258; SZIJÁRTÓ, The Diet..., 124.

38 BÓNIS, The Hungarian Feudal Diet..., 293; RÁCZ, A Historical Insight..., 39; see also: BÓDINÉ BELIZNAI et al., 25; RADY, Law and Ancient Constitution..., 37; SZENTE, Functions of the National Assembly..., 101; and especially concerning the earlier development of the royal council: KUBINYI, 4.

39 BÓDINÉ BELIZNAl et al., 25; RÁCZ, A Historical Insight..., 40; RADY, Law and Ancient Constitution...., 37; SZIJÁRTÓ, The Diet..., 124. 
(establishing the Hungarian constitutional monarchy based on the Belgian model of 1831) ${ }^{40}$ changed the structure of the parliament compared to the 1608 regulations. The only (very important) modification was that the lower chamber was transformed into a modern kind of House of Representatives by the introduction of a limited male suffrage instead of the privilege of the estates concerning the appointment of their ablegati. The second chamber (invariably called "Upper Table") remained unchanged until 1885, but the aristocratichistorical element was kept (though slightly restricted) even after this reform. After a short interruption after the First World War, the Hungarian parliament became bicameral again for the rest of the interwar period, and it has become unicameral (maybe definitively) only in 1945.

\section{Historical names of the Hungarian parliament}

The eminent political thinker and legal scholar of the Hungarian enlightenment, József Hajnóczy (1750-1795) published a book on the Hungarian parliament in 1791, right after the dissolution of the first Hungarian diet since $1765 .{ }^{41}$ In the first chapter of this book written in Latin (official language in Hungary at that time) with the full title De Comitiis Regni Hungariae, deque Organisatione eorundem Dissertatio luris Publici Hungarici [A Public Law Dissertation on the Diet of the Kingdom of Hungary and its Organisation], he has compiled a list of the names used for the denomination of the legislative assemblies in the Hungarian history, based on (and with reference to the year and number of article of) the laws collected in the Corpus luris Hungarici. The list contains not less than thirty-three names, but in major part those are different variations of expressions containing the Latin words comitia, congregatio, conventus/conventio, di(a)eta and parlamentum.

If we look at the names used Europe-wide for the same purpose, we can establish that the Hungarian naming practice was very similar of that of the other European countries functioning in the same or similar political system of Ständestaat (or "estate monarchy"). According to Zoltán Szente, ${ }^{42}$ the following words were applied in the Middle Ages and in the early modern era for legislative assemblies:

- Court (in Latin: curia): in the Iberian peninsula (variations: Cortes, Corts);

- Parliament (in Latin: colloquium, parlamentum): in England, Ireland and Scotland (Parliament) and in some of the Italian principalities (Parlamento);

- Assembly (in Latin: congregatio, conventum): in several different forms throughout the continent, from the Scandinavian things through the German tags right until the Slavic versions like sejm (Poland), sabor (Croatia);

- Estates: in the United Provinces of the Netherlands (Staten-Generaal) and in France (États généraux).

40 CIEGER, András: New Models and Old Traditions: Debates on Parliamentarism in Hungary after the AustroHungarian Settlement of 1867, in: The Ideal of Parliament in Europe since 1800, AERTS, Remieg et al. (eds.), Cham 2019, 77-94, (78).

41 HORVÁTH, Attila: Alkotmányjogi javaslatok és reformok, 1790-1949 [Constitutional Proposals and Reforms, 1790-1949], in: MTA PTI Working Papers in Political Science, 2011, 6, 92-109, (96).

42 See e.g. SZENTE, Zoltán: A korai rendi gyúlések fő jellemzői és intézményei [Main Characteristics and Institutions of the Early Estate Assemblies], in: Parlamenti Szemle, 2017, 1, 5-25, (6); SZENTE, A parlamentek története..., 19. 
In the opinion of the author of the present study, a further distinction is to be made, namely between the different language variations of the word "assembly" and those of the word "diet" (in correct Latin: dieta), because, as we will see in the following, these two have slightly different etymology. As the entire Hungarian parliament was never called "court" (curia), in the next part of this paper we will focus on the use of four characteristic denominations in their order of appearance in the Hungarian historical documents: "parliament"; the several forms of "assembly"; the separate and very popular word "diet"; and the equivalent of "estates" in the Hungarian legal sources: Status et Ordines (not mentioned by Hajnóczy in his book). After these, we will have a quick look at the Hungarian denominations as well.

\section{Parliament (parlamentum)}

The English word "parliament" is now a very popular name of legislative assemblies. Many of the contemporary national assemblies of European countries and also of countries on other continents (obviously emerged under the strong influence of European constitutional law and theory) are called this way, however, in the Middle Ages, the use of this name was rather exceptional. The first known example when a general and nation-wide assembly was called like this is a document of the English king Henry III (1216-1272) from 1244 in which he referred to the assembly leading to the issue of the famous Magna Carta Libertatum as "Parliamentum Runimede, quod fuit inter Dom. Joh. Regem patrem nostrum et barones suos Angliæ". ${ }^{43}$

The etymology of this word is disputed, but we accept the view of those who are saying that it was used as an equivalent (or "bad substitute") 44 of the Latin word colloquium, meaning a personal meeting in order to hold a discourse, ${ }^{45}$ and very probably deriving from the French verb parler ${ }^{46}$ or its Italian version parlare (to talk), both being indirect derivatives of the ancient Greek word mapaßoגn (comparison) with the mediation of the Latin language (parabola). ${ }^{47}$ This etymology seems to be especially well-founded for the cases of medieval assemblies in England or Hungary, as the general scope thereof was that the king could discuss the urgent matters of his realm with a privileged group of his subordinates.

According to Hajnóczy, only one Hungarian assembly was called parlamentum (in the entire form: parlamentum publicum regni), the one convened by Ladislaus IV in $1289 .{ }^{48} \mathrm{He}$ refers to page 150 of the work written by Martinus Georgius Kovachich and published in Buda just one year before the publication of Hajnóczy's book, in 1790, with the full Latin title Vestigia comitiorum apud Hungaros ab exordio regni eorum in Pannonia usque ad hodiernum diem

43 WHITE, Albert B.: Early Uses of "Parliamentum", in: The Modern Language Review, 9, 1914, 1, 92-93, (92 [footnote]).

44 RICHARDSON, Henry G.: The Origins of Parliament, in: Transactions of the Royal Historical Society, 11, 1928, 137-183, (143).

45 Online: https://en.wiktionary.org/wiki/colloquium (Downloaded 21 January 2020); see also: RICHARDSON, 143; SZENTE, A parlamentek története..., 19.

46 Ibidem.

47 Online: https://en.wiktionary.org/wiki/parlare\#Verb (Downloaded 21 January 2020).

48 HAJNÓCZY, József: De Comitiis Regni Hungariae, deque Organisatione eorundem Dissertatio luris Publici Hungarici, Pressburg 1791, 4. 
celebratorum, containing a detailed description of the works of all (presumed or factually proved) legislative assemblies in Hungary since St. Stephen right until the long-awaited convocation of the coronation diet of Leopold II (1790-1792) convened in 1790, after a 25-years interruption of absolutistic form of government of queen Maria Theresa (17401780) and Emperor Joseph II (1780-1790) who cannot be considered constitutionally as a Hungarian king because he had never been crowned.

Hajnóczy's reference to the given page of the Vestigia comitiorium is correct, ${ }^{49}$ and many other authors referred to the same document of 1289 as the only known example of the official use of parlamentum in Hungarian history as well. ${ }^{50}$ More recently, legal historians highlighted that in ecclesiastical sources the (already mentioned) assemblies of legislative character convoked in 1290 and 1298 (by Andrew III) are also named as parlamentum publicum or parlamentum generale. ${ }^{51}$ According to Lajos Rácz, even if it seems obvious, it does not necessarily prove that the model of these assemblies would be the Parliament of England, because historiographical researches discovered a more direct connection with the diet of the Patriarchate of Aquileia on the North Adriatic coast (now belonging to the Italian region of Friuli-Venezia Giulia). ${ }^{52}$

The Hungarian equivalent of the word "parliament" (parlament) is widely known and accepted in our contemporary language as an (unofficial) denomination of the parliament of Hungary. However, in the history of the Hungarian language, it is far newer than the usage of the Latin version (parlamentum). According to our knowledge, its first occurrence is from 1612 in the meaning of legislative assembly, though not referring to the Hungarian diet but the English (or Scottish) parliament, ${ }^{53}$ because the book itself was a Hungarian translation of the famous work of the Scottish king James VI (1567-1625, king of England as James I from 1603), Basilikon Doron (1599), translated to Hungarian by György Szepsi Korotz. In another book written in Hungarian (Angliai Independentismus by Gáspár Miskolczi Csulyak) and published in 1654 in Utrecht (the Netherlands), the word is used in its Latin form (parlamentum), referring to the English parliament and presenting its two chambers to the Hungarian readers. ${ }^{54}$ The Hungarian diet was not referred to as "parlament" until the modern age.

$49 \mathrm{KOVACHICH}$, Martinus Georgius: Vestigia comitiorum apud Hungaros ab exordio regni eorum in Pannonia usque ad hodiernum diem celebratorum, Buda 1790, 150.

50 See e.g.: BEÖTHY, Ákos: A magyar államiság fejlödése, küzdelmei. Politikai tanulmány. I. rész: A régi Magyarország, a honfoglalástól az 1825-iki országgyúlésig [Development and Struggles of the Hungarian Statehood. A Political Study. Part One: the ancient Hungary, from the Conquest until the Diet of 1825], Budapest 1906, 48 (with wrong reference); KMETY, 225 [footnote].

51 BÓDINÉ BELIZNAl et al., 24; RÁCZ, A Historical Insight..., 37; SZENTE, Functions of the National Assembly..., 96 [footnote No. 13]; SZENTE, A parlamentek története..., 119.

52 RÁCZ, A Historical Insight..., 37.

53 According to the linguicist László Országh, the English one [see: ORSZÁGH, László: Parlament, in: Magyar Nyelvör, 94, 1970, 3, 349-350, (350)], in the opinion of the author of this study the Scottish parliament, because James was not yet king of England at the time when his book was published (in 1599).

54 Ibidem, 350 . 


\section{Latin forms of the word assembly}

\section{Congregatio}

Congregatio (with different attributes and combinations thereof) was undoubtedly the most frequently used Latin word for denominating the legislative assemblies in medieval and early modern Hungarian legal documents. ${ }^{55}$ Hajnóczy alone discovered 25 appearances of congregatio in law texts, starting with 1435 (preface of the decree of Sigismund of Luxemburg issued in that year), right up to the $18^{\text {th }}$ century, practically until contemporary times from his point of view. The most frequent form of usage was congregatio generalis, used in not less than twelve articles in different Hungarian laws according to Hajnóczy's research. ${ }^{56}$ According to György Bónis, the attribute generalis referred to the fact that these were nationwide assemblies for all the privileged inhabitants of the realm, instead of partial assemblies for given groups of people, or parts of the country. ${ }^{57}$

Erzsébet S. Kiss mentions in her study that this term very probably derived from ecclesiastical document, as several types of meetings of the clergy were used to be called congregatio generalis, from the assemblies of monastic orders and convents up to the papal synods. In the $13^{\text {th }}$ century, the Hungarian kings and royal officials could easily become aware of this meaning, as it can be seen in the letters written by popes to Hungarian kings (e.g. the letter sent by Pope Innocent III to Andrew III) or prelates. In the Chronicon Pictum ("The Illuminated Chronicle", 58 in Hungarian: "Képes Krónika"), probably written by Márk Kálti, guardian-canon of Székesfehérvár around 1360 on the basis of a mandate received from king Louis I, a judicial assembly held by queen consort (and regent) Elena in 1131 in Arad is mentioned (retrospectively) the first time as congregatio generalis. According to S. Kiss, and contrary to the above cited opinion represented by Bónis, in $13^{\text {th }}$-century royal documents the same expression was used for partial assemblies convened by the kings for different groups of counties as well. ${ }^{59}$

Article XVIII of the decree of 1290 (probably already adopted at a legislative assembly that was, as we have already seen, also mentioned as "parlamentum") is referring to the necessity of convening yearly assemblies as ordered in the Golden Bull with the following words: "in quolibet anno semel omnes barones et nobiles regni nostri Albam ad congregationem debeant convenire" ("once each year all the barons and nobles of the realm shall convene"). ${ }^{60}$ The diets of the $15^{\text {th }}$ century (from 1435 on, until 1498) are also usually called simply as congregatio (e.g. in 1435, 1446, 1478, 1498) or congregatio

55 BÓNIS, The Hungarian Feudal Diet..., 292.

56 HAJNÓCZY, 2-3.

57 BÓNIS, The Hungarian Feudal Diet..., 292.

58 A recent publication in English see: BAK, János M. - VESZPRÉMY, László (eds.): The Illuminated Chronicle. Chronicle of the Deeds of the Hungarians from the Fourteenth-Century Illuminated Codex, Budapest 2018.

59 S. KISS, 11-13.

60 BAK, 194 (Latin) and 202 (English). 
generalis (e.g. in 1446, 1458, 1459, 1462, 1464, 1492, 1495, 1498). ${ }^{61}$ In the preamble of the Tripartitum, Stephen Werböczy also refers to the parliament (to which his great work was presented as a bill) the same way, in the name of king Wladislas II: "Demum nobis in praesenti conventu \& congregatione generali eorundem universorum prelatorum \& baronum, regni huius nobilium..." ("Finally, after we had convened in the present assembly and general gathering of all the same prelates, barons and nobles of this realm...").62

\section{Conventio or conventus}

Further to congregatio, the other most frequently used expression for the parliament in the $15^{\text {th }}$ century was, again based on Hajnóczy's compilation, conventio (in itself in 1446 and 1498, with the attribute generalis e.g. in 1453, 1458, 1471, 1492, 1500 and 1517). An altered form of this word (conventus) was also quite often applied: as conventus generalis (e.g. in 1471, 1550 and 1662) or even as conventus generalis omnium regnicolarum (in 1500), later in a very detailed official form as "Conventus Dominorum Praelatorum, Baronum, Magnatum \& Nobilium, ceterorumque Statutum \& Ordinum Regni Hungariae, partiumque ei subiectarum (alibi annexarum) generalis", i.e. listing all the estates (the chapters and towns only as "the others"). This long version was used several times in the $17^{\text {th }}$ century, and also as late as in $1751 .{ }^{63}$

\section{Comitia}

As we could already see, further to many other sources, from the title of Kovachich's book (Vestigia comitiorum...) and Hajnóczy's work (De Comitiis Regni Hungariae...) as well, in the late $18^{\text {th }}$ century one of the most widely known and preferred names of the Hungarian diet was comitia. ${ }^{64}$ A considerable part of the official publications (in Latin language) of the sessions of the Hungarian parliament held in 1790-91 (coronation of Leopold II), 1792 (coronation of Francis I) and 1796 (attack of French troops against the Habsburg empire) also referred in their titles to the diet by using this word. In order to substantiate this observation, we may mention the official title of the parliamentary diaries of this era (Diarium Comitiorium) and that of the documents (laws) adopted by these diets (Series Actorum in Generalibus Regni Comitiis) as well. ${ }^{65}$

61 As an example, let us cite the first paragraph of Article I of Wladislas II's decree of 1498 on the necessity of convening assemblies annually to the Field of Rákos: "Item, quod amodo infra quatuor annorum spacia post sese immediate consequenter affutura singulis annis ad festum sancti Georgii martyris universis regnicolis, tam scilicet prelatis, quam baronibus, ceterisque nobilibus et possessionatis hominibus per regiam maiestatem in campo Rakos una congregacio generalis indicatur et celebretur" (in English: "Then, that in the four years now following a general assembly shall be annually held by His Majesty at the feast of St George the Martyr for all the gentlemen of the realm, that is the prelates as well as the barons and other nobles and men of property in the field of Rákos"). See: BAK, 921 (Latin) and 945 (English).

62 WERBÖCZY, The Customary Law..., 8-9.

63 HAJNÓCZY, 2-4.

64 SZIJÁRTÓ, István M.: A diéta. A magyar rendek és az országgyúlés, 1708-1792 [The Diet. The Hungarian Estates and the Parliament, 1708-1792], Keszthely 2010, 30 [footnote].

65 All this documents can be read at and downloaded from the collections of the Library of the Hungarian Parliament, online: https://library.hungaricana.hu/hu/collection/orszaggyulesi_konyvtar_dtt_ReformkorElottiDok/ (Downloaded 17 January 2020). 
According to Hajnóczy, the first appearance of comitia in the text of Hungarian laws can already be found as early as in Act VI of 1542 (as comitia generalia), while in the later (1 $7^{\text {th }}$ and $18^{\text {th }}$ ) centuries the word comitia can be found in legal sources in its simple form as well as in attributed forms like comitia regni $(1655,1765)$ or comitia generalia regni $(1741$, 1765). ${ }^{66}$ When the compilation of the Hungarian statute law later (from its famous 1696 edition) known as the Corpus luris Hungarici was first published in 1584, its full title was also "Decreta, constitutiones et articuli regum inclyti Ungariae [...] publiciis comitiis edita" (in English: "Decrees, laws and articles of the noble Kingdom of Hungary [...] adopted at public assemblies").

Furthermore, in Act I (post coronationem) of 1608 (that was, as we mentioned before, the most important regulation concerning the Hungarian parliament until 1848, and remained partially in force until 1944), the terms comitia regni and comitia generalia appear as well. In the first section it is laid down that the scope of the law is to specify whom the king shall invite to the future assemblies: "quive per suam majestatem regiam ad publica regni comitia per suae majestatis regales vocari", while in the final $\left(12^{\text {th }}\right)$ section the law prohibits the king to invite any persons not belonging to the "estates and orders" listed in the previous paragraphs with the following words: "Praeter hos itaque S. S. et O. O. [Status et Ordines] ne sua majestas regia [...] ad comitia generalia adhibeat". ${ }^{67}$

\section{Dieta or diaeta}

According to the eminent researcher of the $18^{\text {th }}$-century Hungarian diets, István M. Szijártó, the parliaments held in this age were the most often referred to in contemporary documents and literature as diaeta, regni comitia (see in the previous section of this study) or diaeta regni. ${ }^{68}$ The word diaeta is misspelled, and this mistake is very probably deriving from the other meaning of diet, the food consumed by a given person or group of people. ${ }^{69}$ Anyway, the fact that this form appeared much more often than the correct form (dieta) in medieval and early modern sources is well reflected in the fact that Hajnóczy does not mention the latter even once. ${ }^{70}$ The etymology of this word is still not clear, however it is presumed by many researchers that it has to be somehow in connection with the Latin word dies (day). Consequently, dieta could have originally meant a daily portion, one day's run or a daily allowance. The German equivalent of day, Tag was (and is still) used as a term meaning assembly. ${ }^{71}$

66 HAJNÓCZY, 1.

67 Source of the Latin text: MARCZALI, Henrik: A magyar történet kútföinek kézikönyve [A Handbook for the Sources of Hungarian History], Budapest 1901, 511-512.

68 SZIJÁRTÓ, A diéta..., 30 [footnote]; see also: BÓNIS, The Hungarian Feudal Diet..., 292; RÁCZ, A Historical Insight..., 37.

69 See e.g. the article "diéta" in: BENKÖ, Loránd (ed.): A magyar nyelv történeti-etimológiai szótára, 1. kötet (A-Gy) [Historical-etimological Dictionary of the Hungarian Language, Volume 1 (A-Gy)], Budapest 1967, 632 and FEJES, László: Diéta és diéta [Diet and Diet], online: https://www.nyest.hu/hirek/dieta-es-dieta (Downloaded 17 January 2020).

70 See HAJNÓCZY, 3-4.

71 BENKÖ, 632; FEJES. 
As it is well known, the imperial diets of the Holy Roman Empire were called Reichstag, while the provincial assemblies Landtag. In Scandinavia, similar terms have been adopted under German influence: riksdag in Sweden, rigsdag in Denmark and Norway. ${ }^{72}$ According to the researches of Géza Pálffy, the contemporary German (imperial and Austrian) sources referred to the Hungarian diet as Landtag, though the use of this word was incorrect, because the characteristics of the Hungarian parliament as a "composite assembly" were preserved even under the rule of Habsburg kings, since the assemblies of Croatia and Slavonia (sabor) and, in the beginning, even the Transylvanian congregatio generalis sent there its deputies. Therefore it should have been rather called Reichstag, similarly to the imperial diet, than Landtag (a provincial assembly). ${ }^{73}$

If we look at the Hungarian historical sources, we can observe that the word "diet" (in the well-known misspelled form diaeta) was already used as early as in $1453 .{ }^{74}$ In Hajnóczy's work (already cited many times in the present study) not less than 14 appearances of diaeta (alone, together with other terms, or with the attribute generalis) are counted from the $15^{\text {th }}$ $18^{\text {th }}$ centuries, right up to Hajnóczy's own times. When the parliament made clear that tax should not be imposed without the approval of the estates (Act I of 1504), the assembly to be convened to the Field of Rákos was (also) referred as the diaeta generalis ("general $\left.\operatorname{diet}^{\prime \prime}\right) .{ }^{75}$ In the enormously important regulation of 1608, further to this form, we can find the expressions generalis regni diaeta ("general diet of the realm") and publica regni diaeta ("public diet of the realm") as well. ${ }^{76}$

Finally, we would like to mention that the famous Hungarian poet, Mihály Csokonai Vitéz (1773-1805) published his one-man journal on the sessions of the parliament in 1796 having chosen the title Diétai magyar múzsa ("Hungarian Muse at the Diet"). ${ }^{77}$ Diéta is the form of the word according to the modern Hungarian spelling, written with a long (accented) é instead of $e$. In the present-day Hungarian language both meanings of diet are still accepted and used in the form "diéta": in colloquial usage as food, while in the historiography as a reference to medieval and early modern Hungarian and foreign parliamentary organs (in case of Hungary, always in the sense of parliaments held before 1848, thus showing the contrast between the estate assemblies and the democratic parliament that is usually referred to as parlament or, more officially, országgyúlés).

72 WICKHAM, Chris: Medieval Europe, New Haven - London 2016, 238; for Scandinavia see e.g. KÉPES, György: A Dán Királyság alkotmánytörténete a kezdetektöl 1848-ig [A Constitutional History of the Kingdom of Denmark from the Beginning to 1848], Budapest 2019, 141-142; SCHÜCK, Herman: Royal Assemblies (Parliaments, Estates), in: Medieval Scandinavia: An Encyclopedia, PULSIANO, Phillip - WOLF, Kirsten (eds.), New York 1993, 544-545, (544).

73 See: PÁLFFY, The Kingdom of Hungary..., 19-20 and 177.

74 BÓNIS, The Hungarian Feudal Diet..., 292; HAJNÓCZY, 3.

75 MARCZALI, 316.

76 Ibidem, 511.

77 All the eleven volumes of this interesting periodical have been published in one book (in reprint) in 1974: CSOKONAI VITÉZ, Mihály: Diétai magyar múzsa, Budapest 1974. 


\section{Status et Ordines}

In the European constitutional history there are two well-known examples where the official name of the medieval and early modern parliament is containing the word "estates". The French diet first convened in 1302 by king Philip IV "the Fair" (1285-1314) in order to gain support from his subordinates in his fight against the Pope was called États généraux (in English translation: "Estates General") 78 until 1614 when its last session was held (and then, for a short time, in 1789 as well), while the powerful federal assembly of the United Provinces of the Netherlands, representing the sovereignty of the Dutch Republic, bore the same name in Dutch, Staten-Generaal that has interestingly remained the name of the democratic parliament of the Netherlands as well, right until today.

If we go back to Hajnóczy's De Comitiis Regni Hungariae and look at his list, we cannot find any similar name in itself, however we may find a long expression containing the Latin term Status et Ordines ("estates and orders"), in the form Conventus Dominorum Praelatorum, Baronum, Magnatum \& Nobilium, ceterorumque Statuum \& Ordinum Regni Hungariae, partiumque ei subiectarum (alibi annexarum) generalis, referred to by Hajnóczy in six decrees (namely: 1625, 1630, 1635, 1638, 1647 and 1655) from the 17 $7^{\text {th }}$, and one (1751) in the $18^{\text {th }}$ century. ${ }^{79}$ If we try to translate this very detailed denomination, we can observe from the usage of the word ceterorumque that it may have been a general reference to "any other" estates not mentioned explicitly before. According to Hajnóczy, in the text of last (from his point of view: recent) laws this long denomination was used "several times" ("Plurimum in ultimis decretis usitatum nomen est..."). ${ }^{80}$

Many scholars emphasise that Status et Ordines was often the synonym for the lower estates represented in the Lower Table of the parliament, i.e. the county nobles, the lower clergy and the burghers. ${ }^{81}$ It is undoubtedly true for the $18^{\text {th }}$ century, however right in Act I (post coronationem) of 1608 this expression was used for the entirety of the Hungarian estates. This very important source of the Hungarian historical constitution starts with the following question: "Quinam Status, et ordines dicantur?" (Who can be called as estates and orders?), 82 and continues with this explanation: "quinam sub nomine statuum et ordinum regni intelligi; quive per suam majestatem regiam ad publica regni comitia per suae majestatis regales vocari, et vota sua in publica regni diaeta habere debeant" (i.e. the ones who are to be invited by his Majesty to the diet and who will have their votes there). Consequently, as György Bónis and Jean Bérenger also observe, the expression Status et Ordines ("karok és rendek") was in use as a general reference to the parliament as a whole as well. ${ }^{83}$

78 WICKHAM, 238.

79 HAJNÓCZY, 3.

80 lbidem, 4.

81 See e.g. KMETY, 243 [footnote]; SZIJÁRTÓ, A diéta..., 328.

82 MARCZALI, 511.

83 BÉRENGER - KECSKEMÉTI, 25; BÓNIS, The Hungarian Feudal Diet..., 292. 


\section{Hungarian terms used for denominating the legislative assembly}

Until the $19^{\text {th }}$ century (1844), the only language used in legal and other official documents in the Kingdom of Hungary was - apart from an unsuccessful attempt of Joseph II in 1784 to introduce German language as the official language of public administration in Hungary as well as in the other countries and provinces of his realm - the Latin. However, especially among the members of the lesser nobility, Hungarian was also widely in use. Though the first complete Hungarian translation of the Corpus luris Hungarici is from as late as 1896, Werbőczy's Tripartitum was published first in an incomplete Hungarian translation by Balázs Weres already in 1565 in Debrecen, and some years later, in 1571 a revised and more complete Hungarian edition was published by Gáspár Heltai in Kolozsvár (now Cluj, Romania). ${ }^{84}$ In the Principality of Transylvania (a semi-independent state since 1570) Hungarian was also used as an official language, ${ }^{85}$ in publication of laws as well..$^{86}$

\section{Rákos}

As already mentioned, because of the ancient privilege of the servientes to attend the meetings "as they wish" (Golden Bull, 1222) and the principle of una eademque nobilitas $(1351,1514)$, there were several occasions in Hungarian history until the second part of the $16^{\text {th }}$ century ${ }^{87}$ when mass assemblies were held, with the personal attendance of hundreds, or even thousands of noblemen from around the country. The location of these, sometimes "tumultuous" assemblies was usually the Field of Rákos, a large open territory close to the castle of Buda where the council meetings (with the prelates, barons and magnates) were held by the king, but at the opposite side of the river Danube, near the town of Pest (united with Buda only in 1873). ${ }^{88}$

The first assembly that summoned here was in May 1277.89 Thirty years later the first Angevin king, Charles I was elected at this place, and so was Wladislas II in 1790 and the two-month old John II Szapolyai (1540-1571, Hungarian "national" counter-king chosen against Ferdinand I) in 1540 as well. The Hungarian nobles made their famous decision

84 RÁCZ, Lajos: Werbőczi István Tripartitumának első fordításai [The First Translation of Stephen Werbőczy's Tripartitum], in: Ünnepi tanulmányok Máthé Gábor 65. születésnapja tiszteletére [Festive Studies in Honour of Gábor Máthé's 65 th Birthday], MEZEY, Barna - RÉVÉSZ, Mihály T. (eds.), Budapest 2006, 453-466, (455-456).

85 TAMÁSNÉ SZABÓ, Csilla: A magyar jogi nyelv az Erdélyi Fejedelemség korában [Hungarian Legal Language in the Era of the Principality of Transylvania], in: A nyelvtörténeti kutatások újabb eredményei, 4, 2006, 173-180, (173).

86 As a nice example for early official Hungarian law texts see: Approbatae constitutiones regni Transylvaniae et partium Hungariae eidem annexarum, Várad [Oradea] 1653, online: https://rmk.hungaricana.hu/hu/RMK_I_878/ (Downloaded 23 January 2020).

87 The last time all Hungarian noblemen were invited in person was the coronation of Archduke Rudolf (king Maximilian I's oldest son and future heir according to the rules of successions of the House of Habsburg accepted by the Hungarian estates at an assembly held in Nagyszombat in 1547) in September 1572. PÁLFFY, The Kingdom of Hungary..., 179; SZENTE, A parlamentek története..., 256. Károly Kmety wrongly indicates this date as 1562 , see KMETY, 243 [footnote].

88 BÓNIS, The Hungarian Feudal Diet..., 293; ENGEL, 349; RADY, Law and Ancient Constitution..., 36; SZENTE, A parlamentek története..., 262.

89 ENGEL, 108; S. KISS, 32. 
("Decision of Rákos") in 1505 also at this site, on electing a Hungarian "national" king for the case Wladislas II would die without heir. The name of this emblematic place of the mass assemblies of Hungarian nobles became a term for the Hungarian diet in the $16^{\text {th }}$-century, however not in Hungary but abroad, especially in Poland - according to Polish spelling, in the form of "rokosz" (in the Polish language the letter "sz" is to be pronounced as English "sh", similarly to the Hungarian "s"). ${ }^{90}$ This name became such popular that even some special assemblies of the confederation of Polish nobles were called rokosz, for example the one convened by the king in 1606 in order to reach the approval of noblemen for an extraordinary tax of war. ${ }^{91}$

According to an article published by Elemér Moór in 1936 in a journal called Népünk és nyelvünk ("Our people and language"), ${ }^{92}$ the Poles very probably adopted their word rokosz as the name of the assembly of the Hungarian nobles from the Slovaks living at the border between the northern part of the historical Kingdom of Hungary called Felvidék (the "upper country", now the territory of the Republic of Slovakia) and Poland. Furthermore, Moór mentions (based on the research of another Hungarian linguist, Béla Iványi $)^{93}$ that there is a document from 1497 in the archive of the margraves of Brandenburg which already referred to the Hungarian diet as Rakusch, and the imperial chancellery of Ferdinand I also used this word in connection with the assemblies of Hungary ${ }^{94}$ However, there is only one known example when the word Rákos was applied as a term for parliament, from $1515 . .^{95}$

\section{Országgyứlés}

The name of the parliament of Hungary is országgyúlés since the Hungarian language was made official by Act II of 1844. In 1848, two of the famous April Laws, Act IV "on the yearly sessions of the parliament" ("az országgyúlés évenkénti üléseirōl") and Act $V$ "on the election of delegates to the parliament based on popular representation" ("az országgyúlési követeknek népképviselet alapján választásáról") contained this word in its titles. ${ }^{96}$ This is a composite word, consisting of two elements, ország (country, realm) on one hand, and gyúlés (assembly) on the other. Basically, it is a literal translation of the Latin expression comitia (generalia) regni that, as we have already seen, was already in use as one of the most frequent forms for denominating the parliament in the late $18^{\text {th }}$ and early $19^{\text {th }}$ centuries. It is interesting to mention, that in the $17^{\text {th }}$ century, the word ország was also used as a synonym of the lower chamber and its members, the regnicolae (in a more complete Hungarian form: "országlakók" meaning "inhabitants of the realm").97

90 BÓNIS, The Hungarian Feudal Diet..., 293; ECKHART, 97; ENGEL, 349.

91 SZENTE, A parlamentek története..., 287.

92 MOÓR, Elemér: Rákos, in: Népünk és nyelvünk, 8, 1936, 179-186.

93 IVÁNYI, Béla: Adalékok régi országgyúléseink Rákos nevéhez [Additions to the name "Rákos" of our old diets], Szeged 1935, 4 [322].

94 MOÓR, 179-180.

95 Ibidem, 181.

96 See: https://net.jogtar.hu/ezer-ev-torveny?docid=84800005.TV and https://net.jogtar.hu/ezer-evtorveny?docid=84800004. TV (Downloaded 24 January 2020).

97 SZIJÁRTÓ, A diéta..., 328; see also BÉRENGER - KECSKEMÉTI, 25; BÓNIS, György - BALOGH, Elemér (eds.): Hübériség és rendiség a középkori magyar jogban [Feudal and Estate Elements in Medieval Hungarian Law], Budapest 2003, 371; SZENTE, A parlamentek története..., 120. 
The first known appearance of the expression országgyúlés (written separately and with contemporary spelling as "orszag gywles") was found by the poet and scholar Gábor Döbrentei (1785-1851) in 1835. It is a judgment from 1560 in a legal dispute concerning a fruitery and vegetable garden that had been, at least according to the claimants, unlawfully taken from a certain nobleman called Péter Czeczey when he had been away, right because of his obligation to attend the diet: "mykor orszag gywlesben wolth" (with modern Hungarian spelling "mikor országgyúlésben volt", in English: "while he was at the assembly of the realm").98 In the late $16^{\text {th }}$ Transylvania where, contrary to the Kingdom of Hungary where Latin kept its privilege, Hungarian was used as an official language, we can also find an ancient example of use of the word gyúlés (assembly). Prince Kristóf Báthory wrote in April 1578 in a letter of invitation to the Transylvanian diet the following "Coloswarat [...] generalis giwlest vegeztwnk celebraltatni" (modern Hungarian: "Kolozsvárott [...] generális gyülést végeztünk celebráltatni", in English: "we have decided that a general assembly would be celebrated in Kolozsvár [Cluj]"). ${ }^{99}$

Another popular variant was the possessive form "ország gyúlése" (meaning literally the "assembly of the realm" or "assembly of the country / land") or even "országunk gyúlése" (the assembly of our country). A good example for the first one can be found in the famous handbook of procedural law Directio Methodica written by János Kitonich (1560-1619), first published in Latin in 1619, and translated to Hungarian in 1651 by János Kászoni (b. 1605), regarding litigations to be brought to the diet as a judicial forum: "Ország gyülésére való Pörök" (with modern spelling: "az ország gyúlésére való perek", in English cca. "litigations belonging to the competence of the assembly of the realm"). ${ }^{100}$ For the other form, we may refer to a letter sent by the Hungarian estates to the Slavonian estates in 1608 about Archduke Matthias, the later Matthias II (called in this letter as the regent) who should not be involved in the affairs of Hungary until "the coming assembly of our country" ("az jövendö Orszagunk Gyölésigh", with modern spelling: "az jövendő országunk gyúléséig"). ${ }^{101}$

The third old version of országgyúlés leads us to the modern official English translation "National Assembly", in the sense of the word national as "country-wide", as a known contemporary synonym for generalis. This version, "országos gyúlés" can also be found in some $17^{\text {th }}$ century documents, such as the Hungarian edition of the Tripartitum published in 1643 in Bártfa (now Bardejov, Slovakia) in which the expression "ad diaetam \& conventione generalem" was translated to "bizonyos hagyot napra, vagy Orszagos gyülesre mennenek" (with modern spelling: "bizonyos hagyott napra vagy országos gyúlésre mennének", in English: "[who are] going to a certain day or general assembly" - that is, at the same time, a

98 DÖBRENTEI, Gábor (ed.): Régi magyar nyelvemlékek, 2. kötet II. Vegyes tárgyú régi magyar iratok, $1342-$ 1599 [Old Memories of the Hungarian Language, Volume 2 Part II. Old Hungarian Documents with Various Topics, 1342-1599], Buda 1840, 167-168.

99 Ibidem, 256.

100 KITONICH, Joannes: Directio Methodica. Processus Judiciarii Juris Consuetudinarii, Inclity Regni Hungariae, Lőcse (Levoča) 1650, 12.

101 DÖBRENTEI, Gábor (ed.): Régi magyar nyelvemlékek, 3. kötet II. Vegyes tárgyú régi magyar iratok, 15401600 [Old Memories of the Hungarian Language, Volume 3 Part II. Old Hungarian Documents with Various Topics, 1540-1600], Buda 1842, 126. 
good proof of the already mentioned connection between the words diaeta and "day"),102 or a very nice example from 1653, right on the first page of the compilation of Transylvanian laws known as Approbatae: "a' közönséges jorol akarván concludálni Országos Gyülésekben" (in English: "wanting to conclude on the general good in national assemblies"). ${ }^{103}$

In the late $18^{\text {th }}$ century, when the publication of the materials of diets (as diaries, bills, adopted laws) became common, the titles of such books usually contained the aforementioned possessive form "ország gyúlése", sometimes even with the attribute "Hungarian": "Magyar ország gyúlése" that can be spelled in a modern form as "Magyarország gyúlése", and in this case it can also be translated simply to "the assembly of Hungary". ${ }^{104}$ We have also found a relatively early example where the two parts of the possessive form were connected to each other with a dash: the Hungarian title of the Acta Comitiorum ("Documents of the Parliament", containing all relevant documents from the letter of invitation and the royal propositiones up to the diaries of the sessions and the laws adopted at the diet, all of them in Latin language only) published in 1807 in Buda is spelled as "Az Ország-Gyúlésének Irásai". ${ }^{105}$ According to the linguists, the use of the dash represents that two separate words are going to be connected more closely to each other, later forming a new, composite word. ${ }^{106}$

\section{Nemzetgyứlés}

As we mentioned in the previous chapter of this study, országgyúlés is a common name for parliaments in the modern Hungarian language, and if it is written in a legal document, book on any other formal publication with capital first letter as "Országgyúlés", we can always be sure that this is about the parliament of Hungary, because our legislative assembly has been officially called like this since the introduction of Hungarian as the official language. ${ }^{107}$ However, there were short periods in Hungarian history, when another official name was used, that is nemzetgyúlés ("national assembly"). We would like to emphasise that the fact that the name Országgyúlés is commonly translated to English as "National Assembly", 108 can be slightly misleading, and in the final part of the present study we would like make an attempt to substantiate this statement.

In the Hungarian language the word "nemzet", which the attribute "nemzeti" ("national") is deriving from, means nation in the sense of "people", the ensemble of citizens, and before 1848 the community of the inhabitants of Hungary having political privileges, Werböczy's "noble-nation". That is why Hajnóczy, at the end of the first chapter of his book containing the list of different names for the Hungarian parliament, does not propose the use of expressions like this in Hungarian, because, according to his enlightened opinion

102 WERBÖCZY, Stephanus: Decretum Latino-Hungaricum sive Tripartitum Opus Juris Consuetudinarii Inclyti Regni Hungariae \& Transylvaniae, Bártfa (Bardejov) 1643, 28.

103 Approbatae constitutiones regni Transylvaniae et partium Hungariae eidem annexarum, 1653, 1.

104 Several examples to this document title can be found at the digital archive of the Library of the Hungarian Parliament, online: https://library.hungaricana.hu/hu/collection/orszaggyulesi_konyvtar_dtt_ReformkorElottiDok/ (Downloaded 17 January 2020).

105 https://library.hungaricana.hu/hu/view/Orszaggyules_ReformkorElottiDok_1807_Ir/?pg=0\&layout=s (Downloaded 24 January 2020).

106 ZSOLDOS, Jenő: Parlament [Parliament], in: Magyar Nyelvőr, 84, 1960, 2, 222-223, (223).

107 See e.g. the official website of the Hungarian parliament, online: https://www.parlament.hu/ (Downloaded 24 January 2020).

108 See the English version of the official website of the Hungarian parliament as an example: https://www. parlament.hu/en/web/house-of-the-national-assembly (Downloaded 24 January 2020). 
based on the principle of popular sovereignty of the $18^{\text {th }}$ century, an assembly cannot be called "national" where only a part of the nation is represented. ${ }^{109}$ From this point of view, the parliament of our time could legitimately be called "National Assembly" in English, because popular representation is nowadays satisfactorily guaranteed by general suffrage. It is not surprising that the Hungarian expressions "nemzeti gyúlés" (national assembly) and "nemzet gyúlése" (assembly of the nation) were first used in Hungary in connection with the Assemblée nationale of the French revolution, already in 1789. The latter ("nemzet gyúlése") has been transformed to the composite word "nemzetgyúlés" very similarly to the formation of the word "országgyúlés" (from "ország gyülése"). ${ }^{110}$ When the first Hungarian legislative assembly based on popular representation (franchise as regulated in Act V of 1848) summoned on 5 July 1848 in Pest (as provided by Act IV of 1848), the legendary poet of the Hungarian 1848, Sándor Petôfi (1823-1849) published a revolutionary poem addressed to its members with the title "A nemzetgyúléshez" ("To the National Assembly"). ${ }^{111}$ Thus, as the lower chamber was renamed to House of Representatives (Képviselöház), the parliament as a whole could have been renamed to nemzetgyúlés as well, but it hasn't been.

However, as we mentioned, there are some periods in the history of the Hungarian parliamentarism when the legislative assembly was officially called nemzetgyúlés instead of országgyúlés. If we look at these, we can find two (maybe cumulative) reasons why this name change could occur. The first era was between 1920 and 1926, when the continuity of the Hungarian historical constitution was restored after the revolutions of 1918-19, but the second chamber (Förendiház) was not reinstated until January 1927. The old Förendiház ceased to exist (by the legal nonsense of self-dissolution) in the flurry of the post-first-world-war events in October 1918. The second period started very similarly: the upper chamber (since 1927 simply called Felsőház, "Upper House") also dissolved itself in practice when all its functionaries resigned on 3 November 1944, two weeks after the arrow-cross movement had been brought to power by Gestapo. The new, provisional assembly organised by the opposition parties and communists under the territories already liberated by the Soviet army in Debrecen, the eastern part of Hungary, became unicameral and was called Ideiglenes Nemzetgyúlés ("Provisional National Assembly").

Consequently, we may observe on one hand that the legislative organ of Hungary was called nemzetgyúlés instead of országgyúlés always in provisional, transitional periods; and on the other hand that, when the word nemzetgyúlés was in use as a denomination, the Hungarian parliament never had a second chamber. By virtue of Act XII of 1926 reinstating the second chamber of the parliament in its position from 1927, i.e. restoring the historic, bicameral structure thereof, it had to be officially called országgyúlés again. After the second world war, the name országgyúlés was brought back by Act XXII of 1947 on the parliamentary elections (already in its Hungarian title: "az országgyúlési választásokról" instead of "a nemzetgyúlési választásokról"). ${ }^{112}$

109 HAJNÓCZY, 8. (For similar reasons, he does not propose the use of the word "ország" [country] either, as the privileged estates represent only a part of the country.) For an interpretation of Hajnóczy's proposals see: BÓNIS, György: Hajnóczy József, Budapest 1954, 235.

110 See: ZSOLDOS, 222-223.

111 Pesti Hírlap, 5 July 1848.

112 See: https://net.jogtar.hu/ezer-ev-torveny?docid=94700022.TV (Downloaded 24 January 2020). 
The questions whether the Hungarian parliament should be called országgyúlés (as it is actually called) or nemzetgyúlés, and that the official English name "National Assembly" is the translation of the first, the latter or both, have less importance from the point of view of our constitutional history than the question whether the parliament should be unicameral or bicameral. According to the Hungarian historical constitution, our legislative assembly should be, and in all periods of our history when the historical constitution was respected, it actually was bicameral. However, in fact, we have not had an upper chamber since November 1944, and it would be impossible to reinstate the original one, and maybe it would not be possible to create a new one either. The same happened in many other European countries as well: the maintenance of bicameral parliaments in non-federal countries has become exceptional. Returning to the question of denomination classified above as secondary, we would like to refer to the Fundamental Law of Denmark of 1953 that transformed the Danish bicameral parliament (earlier called Rigsdag) to a unicameral assembly called Folketing ("Assembly of the People", or with other words: national assembly). Between 1849 and 1953, Folketing was the name of the lower chamber of the parliament of Denmark, thus in 1953 the new, unicameral assembly was simple given the name how the lower chamber had earlier been called. Following this (very well-founded) logic, if we accept that the Hungarian parliament was always called nemzetgyúlés in provisional, transitional periods of history only, it should now bear the name "Képviselóház" ("House of Representatives"), since this was the name of its lower chamber, based on popular representation, between 1848-1918 and 19271944. For a legal historian who adheres to historical terms, the use of name "országgyúlés" for a unicameral parliament will always seem to be a bit problematic.

\section{Conclusion}

Similarly to the diets of other European countries based on a mixture of personal attendance of some privileged groups of the society and the representation of other classes or groups, the Hungarian parliament also has its origins at the turn of the high and late Middle Ages. The first royal assemblies that can already be called parliament were convened in the last decade(s) of the $13^{\text {th }}$ century. The Hungarian diet had no official name. It was usually referred to with Latin expressions known and used in other countries as well, such as congregatio, conventio, comitia and diaeta. The last two became very popular in the early modern period, and the Hungarian historiography often uses the Hungarian version of diaeta ("diéta") in order to distinguish the general assemblies of the estates from the modern parliaments based on popular representation (rather called "parlament"). Interestingly, the Latin equivalent of the latter, parlamentum, was almost never used in the medieval and early modern period, except for some early examples in the late $13^{\text {th }}$ century. For a long time, Hungarian was not accepted as the language of political and legal communication (except for the Principality of Transylvania). In the Kingdom of Hungary it has become official only as late as in 1844. Since then, the name of the Hungarian parliament has been "országgyúlés" (national assembly in the sense of the word "nation" as the country). Another form, "nemzetgyúlés" (national assembly in the sense of the word "nation" as the people) was in use as well, in the literature for a short time already in 1848 (making a comparison with the Assemblée nationale of the French revolution), while 
officially in two brief and provisional periods in the 20 $0^{\text {th }}$ century, 1920-26 and 1945-47 (always referring to the necessity of the establishment of a permanent, definitive parliament that can be finally called "országgyúlés" again). Now, the official Hungarian name of our legislative assembly is therefore Országgyúlés (with majuscule), and its official English name is National Assembly. The word parlament is also commonly used, in the normal speech and in more formal communications as well, however, if we want to refer specifically to the parliament of Hungary, we prefer to apply the word országgyúlés. A good example of this distinction is the fact that the Hungarian parliament can be called "magyar országgyúlés" or "magyar parlament" as well - those two expressions are synonyms of each other - but the European Parliament shall always be called "Európai Parlament", the form "európai országgyúlés" would be more than unusual.

\section{References}

Approbatae constitutiones regni Transylvaniae et partium Hungariae eidem annexarum, Várad [Oradea] 1653, online: https://rmk.hungaricana.hu/hu/RMK_I_878/ (Downloaded 23 January 2020).

BAK, János M. (ed.): Online Decreta Regni Mediaevalis Hungariae. The Laws of the Medieval Kingdom of Hungary, Logan 2019, online: https://digitalcommons.usu.edu/ lib_mono/4 (Downloaded 16 January 2020).

BAK, János M. - VESZPRÉMY, László (eds.): The Illuminated Chronicle. Chronicle of the Deeds of the Hungarians from the Fourteenth-Century Illuminated Codex, Budapest 2018.

BARBER, Malcolm: The Two Cities. Medieval Europe, 1050-1320, London - New York 2004. BENKŐ, Loránd (ed.): A magyar nyelv történeti-etimológiai szótára, 1. kötet (A-Gy) [Historical-etimological Dictionary of the Hungarian Language, Volume 1 (A-Gy)], Budapest 1967.

BEÖTHY, Ákos: A magyar államiság fejlődése, küzdelmei. Politikai tanulmány. I. rész: A régi Magyarország, a honfoglalástól az 1825-iki országgyúlésig [Development and Struggles of the Hungarian Statehood. A Political Study. Part One: the ancient Hungary, from the Conquest until the Diet of 1825], Budapest 1906.

BÉRENGER, Jean - KECSKEMÉTI, Károly: Országgyúlés és parlamenti élet Magyarországon, 1608-1918 [Parliament and Parliamentary Life in Hungary, 1608-1918], Budapest 2008. BÓDINÉ BELIZNAl, Kinga et al.: History of the Hungarian Parliament, in: A magyar országgyúlés történetének képeskönyve [History of the Hungarian Parliament], MEZEY, Barna (ed.), Budapest 1999, 23-37.

BÓNIS, György: The Hungarian Feudal Diet $\left(13^{\text {th }}-18^{\text {th }}\right.$ Centuries), in: Gouvernés et Gouvernants XXV., Bruxelles 1965, 287-307.

BÓNIS, György - BALOGH, Elemér (eds.): Húbériség és rendiség a középkori magyar jogban [Feudal and Estate Elements in Medieval Hungarian Law], Budapest 2003.

CIEGER, András: New Models and Old Traditions: Debates on Parliamentarism in Hungary after the Austro-Hungarian Settlement of 1867, in: The Ideal of Parliament in Europe since 1800, AERTS, Remieg et al. (eds.), Cham 2019, 77-94.

CSEKEY, István: Magyarország alkotmánya [The Constitution of Hungary], Budapest 1943. 
CSOKONAI VITÉZ, Mihály: Diétai magyar múzsa, Budapest 1974.

DÖBRENTEl, Gábor (ed.): Régi magyar nyelvemlékek, 2. kötet II. Vegyes tárgyú régi magyar iratok, 1342-1599 [Old Memories of the Hungarian Language, Volume 2 Part II. Old Hungarian Documents with Various Topics, 1342-1599], Buda 1840.

DÖBRENTEI, Gábor (ed.): Régi magyar nyelvemlékek, 3. kötet II. Vegyes tárgyú régi magyar iratok, 1540-1600 [Old Memories of the Hungarian Language, Volume 3 Part II. Old Hungarian Documents with Various Topics, 1540-1600], Buda 1842.

ECKHART, Ferenc: Magyar alkotmány- és jogtörténet [Hungarian Constitutional and Legal History], Budapest 2000.

ENGEL, Pál: The Realm of St. Stephen. A History of Medieval Hungary, 895-1526, London - New York 2001.

FEJES, László: Diéta és diéta [Diet and Diet], online: https://www.nyest.hu/hirek/dieta-esdieta (Downloaded 17 January 2020).

HAJNÓCZY, József: De Comitiis Regni Hungariae, deque Organisatione eorundem Dissertatio luris Publici Hungarici, Pressburg 1791.

HORVÁTH, Attila: Alkotmányjogi javaslatok és reformok, 1790-1949 [Constitutional Proposals and Reforms, 1790-1949], in: MTA PTI Working Papers in Political Science, 2011, 6, 92-109.

IVÁNYI, Béla: Adalékok régi országgyúléseink Rákos nevéhez [Additions to the name "Rákos" of our old diets], Szeged 1935.

KÉPES, György: A Dán Királyság alkotmánytörténete a kezdetektôl 1848-ig [A Constitutional History of the Kingdom of Denmark from the Beginning to 1848], Budapest 2019.

KITONICH, Joannes: Directio Methodica. Processus Judiciarii Juris Consuetudinarii, Inclity Regni Hungariae, Lőcse (Levoča) 1650.

KMETY, Károly: A magyar közjog tankönyve [Textbook of the Hungarian Public Law], Budapest 1902.

KOVACHICH, Martinus Georgius: Vestigia comitiorum apud Hungaros ab exordio regni eorum in Pannonia usque ad hodiernum diem celebratorum, Buda 1790.

KUBINYI, András: A magyar országgyúlések tárgyalási rendje, 1445-1526 [Operational Rules of the Hungarian Diets, 1445-1526], in: Jogtörténeti Szemle, 8, 2006, 2, 3-11.

MARCZALI, Henrik: A magyar történet kútföinek kézikönyve [A Handbook for the Sources of Hungarian History], Budapest 1901.

MOÓR, Elemér: Rákos, in: Népünk és nyelvünk, 8, 1936, 179-186.

NEUMANN, Tibor: Királyi hatalom és országgyúlés a Jagelló-kor elején [Royal Power and Diet at the Beginning of the Jagiello Era], in: Rendiség és parlamentarizmus Magyarországon, a kezdetektöl 1918-ig [Estates and Parliamentarism in Hungary, from the Beginning to 1918], DOBSZAY, Tamás et al. (eds.), Budapest 2014, 46-54.

ORSZÁGH, László: Parlament, in: Magyar Nyelvőrr, 94, 1970, 3, 349-350.

PÁLFFY, Géza: The Kingdom of Hungary and the Habsburg Monarchy in the Sixteenth Century, New York 2009.

PÁLFFY, Géza: A magyar országgyúlés helyszínei a 16-17. században [Locations of the Hungarian Diet in the $16^{\text {th }}$ and $17^{\text {th }}$ Centuries], in: Rendiség és parlamentarizmus Magyarországon, a kezdetektól 1918-ig [Estates and Parliamentarism in Hungary, from the Beginning to 1918], DOBSZAY, Tamás et al. (eds.), Budapest 2014, 65-87. 
RÁCZ, Lajos: A Historical Insight in the Theory and Organization of the Hungarian State, in: The Hungarian State, 1000-2000, GERGELY, András - MÁTHÉ, Gábor (eds.), Budapest 2000, 17-67.

RÁCZ, Lajos: Werbőczi István Tripartitumának első fordításai [The First Translation of Stephen Werbőczy's Tripartitum], in: Ünnepi tanulmányok Máthé Gábor 65. születésnapja tiszteletére [Festive Studies in Honour of Gábor Máthé's 65 $5^{\text {th }}$ Birthday], MEZEY, Barna RÉVÉSZ, Mihály T. (eds.), Budapest 2006, 453-466.

RADY, Martyn: Hungary and the Golden Bull of 1222, in: Banatica, 24, 2014, 2, 87-108.

RADY, Martyn: Law and Ancient Constitution in Medieval and Early Modern Hungary, in: A History of the Hungarian Constitution. Law, Government and Political Culture in Central Europe, HÖRCHER, Ferenc - LORMAN, Thomas (eds.), London 2019, 29-45.

RICHARDSON, Henry G.: The Origins of Parliament, in: Transactions of the Royal Historical Society, 11, 1928, 137-183.

S. KISS, Erzsébet: A királyi generális kongregáció kialakulásának történetéhez, Szeged 1971. SCHÜCK, Herman: Royal Assemblies (Parliaments, Estates), in: Medieval Scandinavia: An Encyclopedia, PULSIANO, Phillip - WOLF, Kirsten (eds.), New York 1993, 544-545.

SZABO, Béla: Development of Law in Hungary: the First Eight Centuries, in: The Hungarian State, 1000-2000, GERGELY, András - MÁTHÉ, Gábor (eds.), Budapest 2000, 130-167.

SZENTE, Zoltán: Az országgyúlés funkciói a magyar közjogi hagyományban [Functions of the Parliament in the Hungarian Constitutional Tradition], in: Jogtörténeti Szemle, 7, 2005, 2, 9-22.

SZENTE, Zoltán: Functions of the National Assembly Within the Constitutional Tradition of Hungary, in: Annales Universitatis Scientiarum Budapestinensis de Rolando Eötvös Nominatae. Sectio luridica, Budapest 2005, 93-114.

SZENTE, Zoltán: A korai rendi gyúlések fő jellemzői és intézményei [Main Characteristics and Institutions of the Early Estate Assemblies], in: Parlamenti Szemle, 2017, 1, 5-25.

SZENTE, Zoltán: A parlamentek története. A korai rendi gyúlések kialakulásától a modern népképviseleti törvényhozásokig [A History of the Parliaments. From the Birth of the Early Diets to the Modern Parliaments of Democratic Representation], Budapest 2018.

SZIJÁRTÓ, István M.: The Diet: The Estates and the Parliament of Hungary, 17081792, in: Bündnispartner und Konkurrenten des Landesfürsten? Die Stände in der Habsburgermonarchie, AMMERER, Gerhard et al. (eds.), Wien - München 2007, 119-139. SZIJÁRTÓ, István M.: A diéta. A magyar rendek és az országgyúlés, 1708-1792 [The Diet. The Hungarian Estates and the Parliament, 1708-1792], Keszthely 2010.

TAMÁSNÉ SZABÓ, Csilla: A magyar jogi nyelv az Erdélyi Fejedelemség korában [Hungarian Legal Language in the Era of the Principality of Transylvania], in: A nyelvtörténeti kutatások újabb eredményei, 4, 2006, 173-180.

WERBÖCZY, Stephanus: Decretum Latino-Hungaricum sive Tripartitum Opus Juris Consuetudinarii Inclyti Regni Hungariae \& Transylvaniae, Bártfa (Bardejov) 1643.

WERBÖCZY, Stephen: The Customary Law of the Renowned Kingdom of Hungary in Three Parts (1517), Budapest 2005.

WHITE, Albert B.: Early Uses of "Parliamentum", in: The Modern Language Review, 9, 1914, 1, 92-93.

WICKHAM, Chris: Medieval Europe, New Haven - London 2016.

ZSOLDOS, Jenő: Parlament [Parliament], in: Magyar Nyelvőr, 84, 1960, 2, 222-223. 


\section{Author}

Dr. hab. György Képes

Magyar Állam- és Jogtörténeti Tanszék, Állam- és Jogtudományi Kar, Eötvös Loránd Tudományegyetem

Department of History of the Hungarian State and Law, Faculty of Law, Eötvös Loránd University

Egyetem tér 1-3, 1053 Budapest, Hungary

kepes.gyorgy@ajk.elte.hu 